Article

\title{
Livestock-Associated Methicillin-Resistant Staphylococcus aureus (MRSA) in Purulent Subcutaneous Lesions of Farm Rabbits
}

\author{
Vanessa Silva ${ }^{1,2,3,4,+}+$ $)$, Telma de Sousa ${ }^{1,2,3,+} \mathbb{0}$, Paula Gómez ${ }^{5}$, Carolina Sabença ${ }^{1,2,3}$, \\ Madalena Vieira-Pinto ${ }^{6,7}{ }^{(0)}$, Rosa Capita ${ }^{8,9}\left(\mathbb{D}\right.$, Carlos Alonso-Calleja $\left.{ }^{8,9}{ }^{(}\right)$, Carmen Torres ${ }^{5}(\mathbb{C}$,
} José L. Capelo ${ }^{10,11}$, Gilberto Igrejas $1,2,4(1)$ and Patrícia Poeta ${ }^{3,4, *(\mathbb{B}}$

1 Functional Genomics and Proteomics Unit, University of Trás-os-Montes and Alto Douro (UTAD), 5000-801 Vila Real, Portugal; vanessasilva@utad.pt (V.S.); telmaslsousa@hotmail.com (T.d.S.); carolinasabenca@hotmail.com (C.S.); gigrejas@utad.pt (G.I.)

2 Department of Genetics and Biotechnology, University of Trás-os-Montes and Alto Douro (UTAD), 5000-801 Vila Real, Portugal

3 Microbiology and Antibiotic Resistance Team (MicroART), Department of Veterinary Sciences, University of Trás-os-Montes and Alto Douro (UTAD), 5000-801 Vila Real, Portugal

4 Associate Laboratory for Green Chemistry-LAQV, Chemistry Department, Faculty of Science and Technology, University Nova of Lisbon, 2829-516 Lisbon, Portugal

5 Area of Biochemistry and Molecular Biology, University of La Rioja, 26006 Logroño, Spain; paula_gv83@hotmail.com (P.G.); carmen.torres@unirioja.es (C.T.)

6 Veterinary and Animal Science Research Center (CECAV), University of Trás-os-Montes and Alto Douro (UTAD), 5000-801 Vila Real, Portugal; mmvpinto@utad.pt

7 Department of Veterinary Sciences, University of Trás-os-Montes and Alto Douro (UTAD), 5000-801 Vila Real, Portugal

8 Department of Food Hygiene and Technology, Veterinary Faculty, University of León, E-24071 León, Spain; rosa.capita@unileon.es (R.C.); carlos.alonso.calleja@unileon.es (C.A.-C.)

9 Institute of Food Science and Technology, University of León, E-24071 León, Spain

10 BIOSCOPE Group, LAQV@REQUIMTE, Chemistry Department, Faculty of Science and Technology, NOVA University of Lisbon, 2825-466 Almada, Portugal; jlcm@fct.unl.pt

11 Proteomass Scientific Society, 2825-466 Costa de Caparica, Portugal

* Correspondence: ppoeta@utad.pt; Tel.: +35-125-935-04-66; Fax: +35-125-935-06-29

+ These authors are coauthors with same contribution.

Received: 16 March 2020; Accepted: 30 March 2020; Published: 6 April 2020

check for updates

\begin{abstract}
Methicillin-resistant Staphylococcus aureus (MRSA) are one of the main pathogens associated with purulent infections. MRSA clonal complex 97 (CC97) has been identified in a wide diversity of livestock animals. Therefore, we aimed to investigate the antibiotic resistance profiles of MRSA strains isolated from purulent lesions of food-producing rabbits. Samples from purulent lesions of 66 rabbits were collected in a slaughterhouse in Portugal. Samples were seeded onto ORSAB plates with $2 \mathrm{mg} / \mathrm{L}$ of oxacillin for MRSA isolation. Susceptibility to antibiotics was tested by the disk diffusion method against 14 antimicrobial agents. The presence of resistance genes, virulence factors and the immune evasion cluster (IEC) system was studied by polymerase chain reaction. All isolates were characterized by multilocus sequence typing (MLST), agr and spa typing. From the 66 samples analyzed, $16(24.2 \%)$ MRSA were detected. All strains were classified as multidrug-resistant as they were resistant to at least three classes of antibiotics. All isolates showed resistance to penicillin, erythromycin and clindamycin. Seven isolates were resistant to gentamicin and harbored the aac( $\left.6^{\prime}\right)$-Ie-aph (2")-Ia gene. Resistance to tetracycline was detected in 10 isolates harboring the tet $(\mathrm{K})$ gene. The IEC genes were detected in three isolates. MRSA strains belonged to CC97, CC1, CC5, CC15 or CC22. The isolates were assigned to six different spa types. In this study we found a moderate prevalence of multidrug-resistant MRSA strains in food-producing rabbits. This may represent concern for food
\end{abstract}


safety and public health, since cross-contamination may occur, leading to the spread of MRSA and, eventually, the possibility of ingestion of contaminated meat.

Keywords: MRSA; CC97; rabbit; LA-MRSA; lesions; Oryctolagus cuniculus

\section{Introduction}

Oryctolagus cuniculus, commonly known as the European rabbit, is an old species with an enormous ability to adapt to a variety of ecosystems, existing in parallel with — but not dependent on-humans [1,2]. Rabbit meat has excellent dietary and nutritional properties, and is traditional in Mediterranean cuisine [3]. Thus, rabbit farming is a sector of great importance in south-European countries. However, disease outbreaks in the food industry may occur, leading to high economic losses [4]. Slaughterhouses are a key point in monitoring rabbit diseases, as any type of observation and/or information obtained at the slaughterhouse can help to understand and adjust the entire chain [5]. The most frequent lesion found on rabbits' skin is the purulent lesion, which can be simple or multiple, and of different size and location [6]. Cutaneous or subcutaneous abscesses are common findings in rabbits of all ages. These purulent lesions are usually the result of contamination of dermal wounds and invasion of subcutaneous tissue by pyogenic bacteria, of which the following can be highlighted: Staphylococcus (S.) spp. (mainly S. aureus and S. hyicus), Streptococcus spp. and Pasteurella multocida [7]. Contamination of meat by pathogenic agents is a fundamental point in the area of food safety, since it can compromise the health of consumers. Bacteria use superficial wounds on rabbits' skin as a route of entry, which is frequent in rabbits kept in cages or in rabbits of considerable size $[8,9]$. The frequency of multifactorial pathologies in rabbit breeding farms has promoted an excessive use of antibiotics, with the possible presence of residues in meat at dangerous levels and the promotion of antimicrobial resistance in bacteria [10].

One of the main groups of microorganisms that pose a threat to consumers are $S$. aureus strains of animal origin. S. aureus are usually part of the normal microbiota of humans and some animal species without causing disease [11]. These bacteria are ubiquitously distributed in nature, and it is possible to isolate them from various food products, being considered one of the most important contaminants in this area [12]. They are adaptable, opportunistic pathogens that have the ability to cause food poisoning due to their ubiquity and ability to form enterotoxins in food, responsible for causing human disease [13]. Besides being able to adapt to various environmental conditions, S. aureus have the ability to easily acquire resistance to antimicrobials [14]. Methicillin-resistant S. aureus (MRSA) was detected for the first time in 1961 at a hospital in the United Kingdom [15]. MRSA has emerged as a worrisome strain causing a wide variety of illnesses around the world and, although MRSA is primary associated with nosocomial infections, it has been found causing infections in pets, livestock and wild animals [16]. Livestock-associated MRSA (LA-MRSA) often belongs to clonal complex (CC) 398; nevertheless, other MRSA lineages have been identified as associated with LA-MRSA, such as CC1, CC9, CC130, and CC97 [17]. Additionally, livestock have been identified as a reservoir of MRSA, with zoonotic importance [18]. The role of the consumption rabbit as a source of human food makes this species a potential transmitter of genes or resistant bacteria to other animals and even to humans [5]. Therefore, this study aimed to characterize the antimicrobial resistance of MRSA strains isolated from purulent skin lesions of rabbits for consumption, and to determine the genetic lineages of these strains.

\section{Materials and Methods}

\subsection{Samples and Bacterial Isolates}

In a period of four months (from June 2018 to September 2018), 66 pus samples were collected from purulent lesions of rabbits (Oryctolagus cuniculus) in a slaughterhouse in the north of Portugal, during 
the daily tasks related to the sanitary inspection of these animals. One sample was collected from each animal. The samples were kept in refrigeration until further characterization. Samples were placed into liquid Brain Heart Infusion (BHI) with $6.5 \% \mathrm{NaCl}$ and incubated at $37^{\circ} \mathrm{C}$ for $24 \mathrm{~h}$. For S. aureus and MRSA isolation, $150 \mu \mathrm{L}$ of the BHI broth was spread onto Oxacillin Resistance Screening Agar Base (ORSAB) plates supplemented with $2 \mathrm{mg} / \mathrm{mL}$ of oxacillin and Mannitol Salt Agar (MSA) plates and incubated at $37^{\circ} \mathrm{C}$ for $24 \mathrm{~h}$. One colony from each plate was recovered. S. aureus were identified by biochemical tests (Gram staining, DNase and catalase) and by multiplex PCR of the genes $16 \mathrm{~S}$ rDNA, nuc and mecA.

\subsection{Antimicrobial Susceptibility Testing}

The phenotypic resistance characterization of the MRSA isolates was performed by the Kirby-Bauer disk diffusion method and according to CLSI 2017 guidelines [19]. Fourteen antibiotics were tested: mupirocin (MUP, $5 \mu \mathrm{g} / \mathrm{disc}$ ), tetracycline (TET, $30 \mu \mathrm{g} / \mathrm{disc}$ ), trimethoprim-sulfamethoxazole (SXT, 1.25/23.75 $\mu \mathrm{g} /$ disc), fusidic acid (FD, $10 \mu \mathrm{g} /$ disc), erythromycin (ERY, $15 \mu \mathrm{g} /$ disc), clindamycin (DA, $2 \mu \mathrm{g} / \mathrm{disc}$ ), gentamicin (CN, $10 \mu \mathrm{g} / \mathrm{disc})$, tobramycin (TOB, $10 \mu \mathrm{g} / \mathrm{disc})$, penicillin (PEN, $10 \mathrm{U} / \mathrm{disc}$ ), linezolid (LNZ, $30 \mu \mathrm{g} / \mathrm{disc}$ ), cefoxitin (FOX, $30 \mu \mathrm{g} /$ disc), chloramphenicol (CHL, $30 \mu \mathrm{g} / \mathrm{disc}$ ), ciprofloxacin (CIP, $5 \mu \mathrm{g} / \mathrm{disc})$ and kanamycin (K,30 $\mu \mathrm{g} / \mathrm{disc})$. S. aureus strain ATCC 25,923 was used as quality control in the susceptibility assays.

\subsection{Antibiotic Resistance Genes and Virulence Factors}

The antibiotic resistance genes and virulence factors were determined by PCR with specific primers and conditions as described previously [20-23]. For the study of resistance to various antibiotics, several resistance genes were tested: $\operatorname{tet}(\mathrm{K}), \operatorname{tet}(\mathrm{M}), \operatorname{tet}(\mathrm{L}), \operatorname{tet}(\mathrm{O}), \operatorname{erm}(\mathrm{A}), \operatorname{erm}(\mathrm{B}), \operatorname{erm}(\mathrm{C}), \operatorname{erm}(\mathrm{T}), \operatorname{msr}(\mathrm{A} / \mathrm{B})$, $m p h \mathrm{C}, \operatorname{lin} \mathrm{A}, \operatorname{lin} \mathrm{B}, v g a \mathrm{~A}, v g a \mathrm{~B}, v g a \mathrm{C}, v g a \mathrm{E}, c f r, \operatorname{acc}\left(6^{\prime}\right)-\mathrm{Ie}-\operatorname{aph}\left(2^{\prime \prime}\right)-\mathrm{Ia}, \operatorname{aph}\left(3^{\prime}\right)-\mathrm{III}$, $\operatorname{ant}\left(4^{\prime}\right)-\mathrm{Ia}, \operatorname{ant}\left(6^{\prime}\right)-\mathrm{Ia}$, blaZ, mupA, fusA, fusB and fusC. The genes tested for virulence were hla, hlb, eta, etb tst, cna and Panton-Valentine leucocidin (PVL) (lukF/lukS-PV). The presence of the immune evasion cluster (IEC) system was detected by screening for the presence of the scn gene (common to all IEC groups), and after by the screening for chp, sak, sea and sep genes, determining the IEC group from the combination of these genes [24]. Positive and negative controls from the University of Trás-os-Montes and Alto Douro, Vila Real, Portugal, were used.

\subsection{Molecular Typing}

All MRSA were characterized by agr-typing (I-IV) using specific primers [25,26]. The isolates were further characterized by spa-typing and multilocus sequence typing (MLST) by PCR and sequencing, and compared to the Ridom SpaServer (http://spaserver.ridom.de) and MLST (https://pubmlst.org/) databases $[27,28]$.

\section{Results}

Of the 66 pus samples collected, 50 S. aureus $(76 \%)$ were isolated. Screening for MRSA isolates allowed the identification of $16(24 \%)$ strains, and only these strains were further characterized. MRSA isolates showed resistance to penicillin $(n=16)$, erythromycin $(n=16)$, clindamycin $(n=16)$, cefoxitin $(n=14)$, oxacillin $(n=13)$, ciprofloxacin $(n=13)$, tetracycline $(n=10)$, kanamycin $(n=7)$, gentamicin $(n=7)$, tobramycin $(n=7)$ and fusidic acid $(n=3)$ (Table 1$)$. None of the isolates exhibited resistance to trimethoprim-sulfamethoxazole, linezolid, vancomycin, chloramphenicol or mupirocin. The genotype results for the $n u c$, rDNA $16 \mathrm{~S}$ and mecA genes were positive, allowing us to conclude that all the isolates were methicillin-resistant $S$. aureus, as expected. Among the isolates resistant to macrolides and lincosamides, the majority harbored the $\operatorname{erm} \mathrm{C}(n=15)$ gene, followed by the $\operatorname{erm} \mathrm{B}(n=4), m s r(\mathrm{~A} / \mathrm{B})$ $(n=2), v g a \mathrm{~B}(n=2), \operatorname{vg} a \mathrm{~A}(n=1)$ and $\operatorname{lin} \mathrm{B}(n=1)$ genes. The genes conferring resistance to tetracycline were analyzed, and all tetracycline-resistant isolates harbored the tet $(\mathrm{K})$ gene and one isolate had both tet $(\mathrm{K})$ and tet $(\mathrm{L})$ genes. Resistance to aminoglycosides were detected in seven isolates and all were 
positive to $a a c\left(6^{\prime}\right)$-Ie-aph (2')-Ia gene. Regarding the virulence factors, all isolates except one harbored the $h l b$ gene, 13 isolates were positive for $c n a$ and the eta gene was detected in only one isolate. All isolates were PVL-negative and the scn gene was detected in three isolates which were ascribed to type $\mathrm{B}$ and C. All isolates were agr type III. MLST analysis showed that the most common ST was ST2855, detected in $50 \%$ of the isolates, and categorized as clonal complex CC97. The remaining isolates were ascribed to five sequence types (ST105, ST582, ST5, ST22 and ST1) included in clonal complexes CC5, $\mathrm{CC} 15, \mathrm{CC} 22$ and CC1. Among the 16 MRSA isolates, six different spa-types were detected (t1190, t002, $\mathrm{t} 2802, \mathrm{t} 084, \mathrm{t} 032$ and $\mathrm{t} 1491$ ), with spa-types $\mathrm{t} 1190$ and $\mathrm{t} 2802$ being the predominant ones.

Table 1. Genetic characterization of antibiotic resistance and molecular typing of methicillin-resistant Staphylococcus aureus (MRSA) isolates from rabbits. CN: gentamicin; DA: clindamycin; CIP: ciprofloxacin; ERY: erythromycin; FD: fusidic acid; FOX: cefoxitin; IEC: immune evasion cluster; PEN: penicillin; PVL: Panton-Valentine leucocidin; TET: tetracycline; TOB: tobramycin.

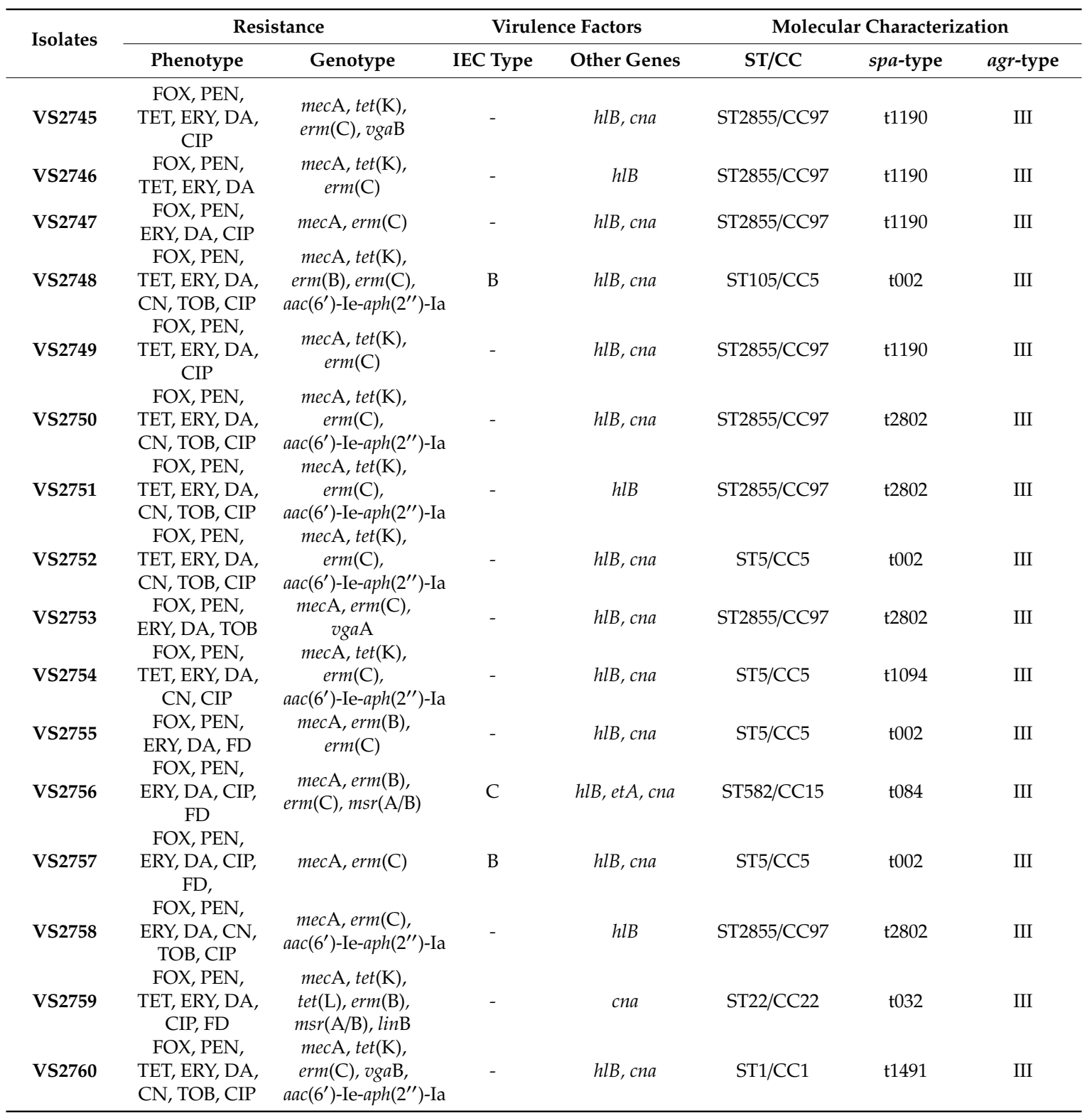

\section{Discussion}

Dermatitis and purulent lesions are the main prominent S. aureus infections in rabbits [29]. Purulent subcutaneous lesions (i.e., abscesses) are relevant due to the technical impact they present in 
slaughterhouses, as well as in the economic sector and animal welfare. In this study, MRSA strains were found in $24 \%$ of samples analyzed, which is in agreement with other studies that reported the presence of $S$. aureus and MRSA in purulent lesions of farm rabbits [30,31]. Given the resistance to three or more different antibiotic classes found in all isolates, all MRSA were classified as multidrug-resistant.

\subsection{Characterization of CC97 MRSA Isolates}

The great majority of the isolates were ascribed to ST2855, which is included in clonal complex CC97. This particular ST was only reported in two recent studies, conducted in Portugal and Spain, in wild hares and farm rabbits [31,32]. These results suggest that ST2855 may either be associated with lagomorphs or be endemic of the Iberian peninsula [32]. The study conducted with farm animals evaluated the presence of MRSA in rabbit lesions. However, unlike our study, no MRSA was found in abscesses [31]. Although CC97 has been previously identified in both community and LA-MRSA, this clonal complex is frequently associated with livestock, particularly ruminants and pigs [33]. Moreover, CC97 is one of the major MRSA clonal complexes in bovines and a leading cause of bovine mastitis worldwide [34]. In Portugal, the presence of this clone has been reported among healthy bovines [35]. CC97 isolates belonged to either spa-type $\mathrm{t} 1190$ or t2802. spa-type $\mathrm{t} 1190$ is a rabbit-specific strain since it has been previously found in rabbit meat [36,37] and lesions [38]. As for spa-type t2802, it has been reported mostly associated with bovine livestock but also with humans [39,40]. All CC97 isolates lacked the IEC genes associated with human adaptation, clearly pointing to an animal origin. Furthermore, five of the eight CC97 MRSAs showed resistance to tetracycline, conferred by the tet $(\mathrm{K})$ gene, which, along with IEC-negative and based on epidemiological evidence, is an indication of animal origin [41]. As in our study, in other studies reporting the presence of CC97 MRSA, the isolates are frequently multidrug resistant with resistance only to $\beta$-lactams and tetracyclines but also to macrolides, lincosamides and aminoglycosides [17,31]. Although the relationship between antibiotic resistance profiles and clonal complexes is still not clear, some studies suggest that different LA-MRSA clones may present specific resistance patterns [42]. Macrolide-lincosamide-streptogramin (MLS) resistance occurs by the cross-resistance among these antibiotics, and bacteria with resistance to MLS were previously reported to be transmitted from animals to humans through the food chain [43]. Resistance to macrolides and lincosamides was detected in all CC97 MRSA isolates. Although it is assumed that erm (A) or erm (C) genes predominate in S. aureus, erm (C) was the most prevalent in this study. The erm genes are highly associated with MLS resistance since these genes cause a 23S rRNA methylation leading to a ribosomal alteration [44]. Three CC97 isolates also presented resistance to gentamicin and harbored the $a a c\left(6^{\prime}\right)$-Ie-aph( $\left.2^{\prime \prime}\right)$-Ia gene. The accessory gene regulator ( $\left.a g r\right)$ system of S. aureus regulates numerous virulence and pathogenicity factors. CC97 MRSA strains have been repeatedly typed as agr type I in pigs and bovine isolates $[17,45,46]$. Nevertheless, in our study all CC97 isolates belonged to agr type III, which may be characteristic of ST2855 since in the only study reporting ST2855 in rabbits, all ST2855 isolates from farm rabbit infections were also typed as agr III [31]. Studies have tried to find a relationship between the type of agr and the type of infections and toxins produced by S. aureus and, although agr III MRSA isolates are often tst-positive, in our study the tst gene was not identified [47,48].

\subsection{Characterization of Non-CC97 MRSA Isolates}

Regarding the non-CC97 MRSA isolates, they were typed into CC1, CC5, CC15 and CC22. Only one isolate was attributed to CC1, which is a clone that seems to have a low host specificity. CC1 has been identified in human infections as part of community transmission, but it has also been isolated from animals, namely, horses, bovines and pigs [33,49]. The CC1 isolate was typed as spa-type t1491, which is generally associated with methicillin-susceptible S. aureus (MSSA) and has been identified in pigs and humans $[50,51]$. One isolate belonged to CC15 and spa-type t084. CC15 has been widely described in the literature, but this clone is typically linked with MSSA [52]. As for spa t084, it has been described as being associated with this clonal complex [53]. The remaining isolates belonged to 
the classical human MRSA lineages CC2 and CC5. The CC15 and two CC5 isolates also contained the IEC genes and were typed as IEC-B and $-C$, respectively. The presence of IEC genes suggests a human origin and possibly a human contamination, which is not very surprising since these clones are usually associated with human infections [54]. Furthermore, the detection of IEC-positive MRSA strains out of the human niche is rare [55]. As with MRSA ST398 often originating in pigs, in which most isolates are resistant to tetracycline, in our study a total of 10 (out of 16) also presented resistance to tetracycline [56]. Out of the eight non-CC97 isolates, five showed resistance to tetracycline conferred by the tet $(\mathrm{K})$ gene and one isolate also harbored tet $(\mathrm{L})$. Resistance to tetracycline can be acquired by tet $(\mathrm{M})$ and tet $(\mathrm{O})$ genes which are located in transposon or chromosome and/or by tet $(\mathrm{K})$ and tet $(\mathrm{L})$ genes located in plasmids [57]. Some of these plasmids carried additional resistance genes, such as the macrolide resistance gene erm(B) [58]. Unlike CC97-MRSA isolates, which harbored only the erm(C) gene conferring resistance to macrolides, the non-CC97 isolates also hosted the $\operatorname{erm}(\mathrm{B})(n=4)$ and $m s r(\mathrm{~A} / \mathrm{B})(n=2)$.

Farm animals are often in contact with bacteria present in the environment where they are raised, thus increasing the likelihood of genetic information exchange between animal and environmental or even human bacteria, allowing commensal bacteria to gain certain genes that give them resistance to several antibiotics $[59,60]$. The overuse of antibiotics in the food-producing animal sector also contributes to antibiotic resistance. It is also important to point out that, in Portugal, the main antibiotics used in cuniculture are tetracyclines and polymyxins. In this study, more than half of isolates showed resistance to tetracycline, which may reflect the overuse of this class of antibiotics in consumption rabbits. These resistances can later be transferred directly to the human microbiome [61]. Antibiotics are often provided to food-producing animals without prior culture and antibiotic susceptibility testing, which makes these animals an ideal reservoir for multidrug-resistant bacteria [62]. Additionally, animals arriving at slaughterhouses often carry $S$. aureus strains, not only causing infection but also as asymptomatic colonizers.

\section{Conclusions}

Food-producing animals, particularly rabbits, may be a reservoir of multidrug-resistant MRSA strains that can be considered an important issue in terms of food safety. The prevalence of bacteria resistant to antibiotics often used in human medicine is alarming. MRSA are increasingly affecting the animal world. New types of MRSA are emerging in several species of animals, and this may become a threat to human health through occupational exposure. In this study, the rate of MRSA strains found infecting rabbits is a concern, since the transmission of MRSA strains from rabbit to human or between rabbits may occur. Moreover, some of our MRSA strains had a human origin and we can hypothesize that animal handlers and farmers might be a source of contamination and transmission of these strains. This study allows veterinarians and those responsible for the farms to have a better understanding of the possible causes of the occurrence of these purulent lesions in animals, to treat them more effectively through appropriate antibiotic use and to be more cautious in terms of biosafety in slaughterhouses.

Author Contributions: Methodology, V.S., T.d.S. and P.G.; Validation, C.T., G.I. and P.P.; Investigation, V.S., T.d.S., P.G., C.S., R.C. and C.A.C.; Resources, M.V.-P.; Writing-Original Draft Preparation, V.S.; Supervision, C.T., J.L.C., G.I. and P.P.; Funding Acquisition, R.C. and C.A.-C. All authors have read and agreed to the published version of the manuscript.

Funding: This research was founded by the Ministerio de Ciencia, Innovación y Universidades (Spain, Project RTI2018-098267-R-C33) and the Junta de Castilla y León (Consejería de Educación, Spain, Project LE164G18).

Acknowledgments: This work was funded by the R\&D Project CAREBIO2-Comparative assessment of antimicrobial resistance in environmental biofilms through proteomics-towards innovative theranostic biomarkers, with reference to NORTE-01-0145-FEDER-030101 and PTDC/SAU-INF/30101/2017, financed by the European Regional Development Fund (ERDF) through the Northern Regional Operational Program (NORTE 2020) and the Foundation for Science and Technology (FCT). This work was supported by the Associate Laboratory for Green Chemistry-LAQV which is financed by national funds from FCT/MCTES (UIDB/50006/2020). Vanessa Silva is grateful to FCT (Fundação para a Ciência e a Tecnologia) for financial support through PhD grant SFRH/BD/137947/2018. 
Conflicts of Interest: None to declare.

\section{References}

1. Branco, M.; Monnerot, M.; Ferrand, N.; Templeton, A.R. Postglacial dispersal of the european rabbit (Oryctolagus cuniculus) on the iberian peninsula reconstructed from nested clade and mismatch analyses of mitochondrial dna genetic variation. Evolution (N. Y.) 2002, 56, 792-803.

2. Brown, S.C.; Wells, K.; Roy-Dufresne, E.; Campbell, S.; Cooke, B.; Cox, T.; Fordham, D.A. Models of spatiotemporal variation in rabbit abundance reveal management hotspots for an invasive species. Ecol. Appl. 2020. [CrossRef] [PubMed]

3. Rampin, F.; Piccirillo, A.; Schiavon, E.; Poppi, L.; Grilli, G. Detection of pathological lesions in slaughtered rabbits. Ital. J. Anim. Sci. 2008, 7, 105-111. [CrossRef]

4. Hussain, M.A.; Dawson, C.O. Economic Impact of Food Safety Outbreaks on Food Businesses. Foods (Basel, Switzerland) 2013, 2, 585-589. [CrossRef]

5. Jenni, L.; Janne, L. Compliance in slaughterhouses and control measures applied by official veterinarians. Food Control 2016, 68, 133-138. [CrossRef]

6. Hermans, K.; Devriese, L.A.; Haesebrouck, F. Rabbit staphylococcosis: Difficult solutions for serious problems. Vet. Microbiol. 2003, 91, 57-64. [CrossRef]

7. Rodríguez-Calleja, J.M.; García-López, I.; Santos, J.A.; Otero, A.; García-Lopez, M.-L. Molecular and phenotypic typing of Staphylococcus aureus isolates from rabbit meat. Res. Microbiol. 2006, 157, 496-502. [CrossRef]

8. Gonzalez, C.D.; Ledo, C.; Cela, E.; Stella, I.; Xu, C.; Ojeda, D.S.; Frenette, P.S.; Gómez, M.I. The good side of inflammation: Staphylococcus aureus proteins SpA and Sbi contribute to proper abscess formation and wound healing during skin and soft tissue infections. Biochim. Biophys. Acta Mol. Basis Dis. 2019, 1865, 2657-2670. [CrossRef]

9. Traverso, S.D.; da Cunha, L.; Fernandes, J.C.T.; Loretti, A.P.; Rhoden, A.; Wunder, E., Jr.; Driemeier, D. Mastite com lesões sistêmicas por Staphylococus aureus subesp. aureus em coelhos. Ciência Rural 2003, 33, 373-376. [CrossRef]

10. Dalle Zotte, A. Perception of rabbit meat quality and major factors influencing the rabbit carcass and meat quality. Livest. Prod. Sci. 2002, 75, 11-32. [CrossRef]

11. Haag, A.F.; Fitzgerald, J.R.; Penadés, J.R. Staphylococcus aureus in Animals. In Gram-Positive Pathogens; ASM Press: Dulles, VA, USA, 2019; pp. 731-746.

12. Kadariya, J.; Smith, T.C.; Thapaliya, D. Staphylococcus aureus and Staphylococcal Food-Borne Disease: An Ongoing Challenge in Public Health. Biomed Res. Int. 2014, 2014, 827965. [CrossRef] [PubMed]

13. Fisher, E.L.; Otto, M.; Cheung, G.Y.C. Basis of Virulence in Enterotoxin-Mediated Staphylococcal Food Poisoning. Front. Microbiol. 2018, 9, 436. [CrossRef] [PubMed]

14. Yoon, H.J.; Choi, J.Y.; Lee, K.; Yong, D.; Kim, J.M.; Song, Y.G. Accessory gene regulator group polymorphisms in methicillin-resistant Staphylococcus aureus: An association with clinical significance. Yonsei Med. J. 2007, 48, 176-183. [CrossRef] [PubMed]

15. Das, R.; Sebastian, S.; Kapil, A.; Dhawan, B. Decline of Nosocomial Methicillin-Resistant Staphylococcus aureus Skin and Soft Tissue Infections in an Indian Tertiary Hospital: Hope for the Future. J. Clin. Diagn. Res. 2017, 11, DL01-DL02. [CrossRef]

16. Bengtsson-Palme, J.; Kristiansson, E.; Larsson, D.G.J. Environmental factors influencing the development and spread of antibiotic resistance. FEMS Microbiol. Rev. 2018, 42, fux053. [CrossRef]

17. Feltrin, F.; Alba, P.; Kraushaar, B.; Ianzano, A.; Argudín, M.A.; Di Matteo, P.; Porrero, M.C.; Aarestrup, F.M.; Butaye, P.; Franco, A.; et al. A Livestock-Associated, Multidrug-Resistant, Methicillin-Resistant Staphylococcus aureus Clonal Complex 97 Lineage Spreading in Dairy Cattle and Pigs in Italy. Appl. Environ. Microbiol. 2016, 82, 816-821. [CrossRef]

18. Elstrøm, P.; Grøntvedt, C.A.; Gabrielsen, C.; Stegger, M.; Angen, Ø.; Åmdal, S.; Enger, H.; Urdahl, A.M.; Jore, S.; Steinbakk, M.; et al. Livestock-Associated MRSA CC1 in Norway; Introduction to Pig Farms, Zoonotic Transmission, and Eradication. Front. Microbiol. 2019, 10, 139. [CrossRef]

19. CLSI Clinical and Laboratory Standards Institute. Performance Standards for Antimicrobial Susceptibility Testing; Clinical and Laboratory Standards Institute: Wayne, PA, USA, 2017. 
20. Silva, V.; Almeida, F.; Silva, A.; Correia, S.; Carvalho, J.A.; Castro, A.P.; Ferreira, E.; Manageiro, V.; Caniça, M.; Igrejas, G.; et al. First report of linezolid-resistant cfr-positive methicillin-resistant Staphylococcus aureus (MRSA) in humans in Portugal. J. Glob. Antimicrob. Resist. 2019, 17, 323-325. [CrossRef]

21. Yu, F.; Liu, Y.; Lv, J.; Qi, X.; Lu, C.; Ding, Y.; Li, D.; Liu, H.; Wang, L. Antimicrobial susceptibility, virulence determinant carriage and molecular characteristics of Staphylococcus aureus isolates associated with skin and soft tissue infections. Braz. J. Infect. Dis. 2015, 19, 614-622. [CrossRef]

22. Jarraud, S.; Mougel, C.; Thioulouse, J.; Lina, G.; Meugnier, H.; Forey, F.; Etienne, J.; Vandenesch, F.; Nesme, X. Relationships between Staphylococcus aureus Genetic Background, Virulence Factors, agr Groups (Alleles), and Human Disease. Infect. Immun. 2002, 70, 631-641. [CrossRef]

23. Lina, G.; Piemont, Y.; Godail-Gamot, F.; Bes, M.; Peter, M.-O.; Gauduchon, V.; Vandenesch, F.; Etienne, J. Involvement of Panton-Valentine Leukocidin-Producing Staphylococcus aureus in Primary Skin Infections and Pneumonia. Clin. Infect. Dis. 1999, 29, 1128-1132. [CrossRef] [PubMed]

24. van Wamel, W.J.B.; Rooijakkers, S.H.M.; Ruyken, M.; van Kessel, K.P.M.; van Strijp, J.A.G. The innate immune modulators staphylococcal complement inhibitor and chemotaxis inhibitory protein of Staphylococcus aureus are located on beta-hemolysin-converting bacteriophages. J. Bacteriol. 2006, 188, 1310-1315. [CrossRef] [PubMed]

25. Shopsin, B.; Mathema, B.; Alcabes, P.; Said-Salim, B.; Lina, G.; Matsuka, A.; Martinez, J.; Kreiswirth, B.N. Prevalence of Specificity Groups among Staphylococcus aureus Strains Colonizing Children and Their Guardians. J. Clin. Microbiol. 2003, 41, 456-459. [CrossRef] [PubMed]

26. Zhang, K.; McClure, J.-A.; Elsayed, S.; Louie, T.; Conly, J.M. Novel Multiplex PCR Assay for Characterization and Concomitant Subtyping of Staphylococcal Cassette Chromosome mec Types I to V in Methicillin-Resistant Staphylococcus aureus. J. Clin. Microbiol. 2005, 43, 5026-5033. [CrossRef]

27. Enright, M.C.; Day, N.P.; Davies, C.E.; Peacock, S.J.; Spratt, B.G. Multilocus sequence typing for characterization of methicillin-resistant and methicillin-susceptible clones of Staphylococcus aureus. J. Clin. Microbiol. 2000, 38, 1008-1015. [CrossRef]

28. Harmsen, D.; Claus, H.; Witte, W.; Rothgänger, J.; Claus, H.; Turnwald, D.; Vogel, U. Typing of Methicillin-Resistant Staphylococcus aureus in a University Hospital Setting by Using Novel Software for spa Repeat Determination and Database Management. J. Clin. Microbiol. 2003, 41, 5442-5448. [CrossRef]

29. Corpa, J.M.; Hermans, K.; Haesebrouck, E. Main pathologies associated with Staphylococcus aureus infections in rabbits: A review. World Rabbit Sci. 2010, 17. [CrossRef]

30. Agnoletti, F.; Mazzolini, E.; Bacchin, C.; Bano, L.; Berto, G.; Rigoli, R.; Muffato, G.; Coato, P.; Tonon, E.; Drigo, I. First reporting of methicillin-resistant Staphylococcus aureus (MRSA) ST398 in an industrial rabbit holding and in farm-related people. Vet. Microbiol. 2014, 170, 172-177. [CrossRef]

31. Moreno-Grúa, E.; Pérez-Fuentes, S.; Muñoz-Silvestre, A.; Viana, D.; Fernández-Ros, A.B.; Sanz-Tejero, C.; Corpa, J.M.; Selva, L. Characterization of Livestock-Associated Methicillin-Resistant Staphylococcus aureus Isolates Obtained From Commercial Rabbitries Located in the Iberian Peninsula. Front. Microbiol. 2018, 9, 1812. [CrossRef]

32. Silva, V.; Pereira, J.E.; Maltez, L.; Ferreira, E.; Manageiro, V.; Caniça, M.; Capelo, J.L.; Igrejas, G.; Poeta, P. Diversity of methicillin-resistant staphylococci among wild Lepus granatensis: First detection of mecA-MRSA in hares. FEMS Microbiol. Ecol. 2020, 96. [CrossRef]

33. Cuny, C.; Wieler, L.; Witte, W. Livestock-Associated MRSA: The Impact on Humans. Antibiotics 2015, 4, 521-543. [CrossRef] [PubMed]

34. Spoor, L.E.; McAdam, P.R.; Weinert, L.A.; Rambaut, A.; Hasman, H.; Aarestrup, F.M.; Kearns, A.M.; Larsen, A.R.; Skov, R.L.; Fitzgerald, J.R. Livestock Origin for a Human Pandemic Clone of Community-Associated Methicillin-Resistant Staphylococcus aureus. MBio 2013, 4, e00356-13. [CrossRef] [PubMed]

35. Conceição, T.; de Lencastre, H.; Aires-de-Sousa, M. Healthy Bovines as Reservoirs of Major Pathogenic Lineages of Staphylococcus aureus in Portugal. Microb. Drug Resist. 2017, 23, 845-851. [CrossRef] [PubMed]

36. Boswihi, S.S.; Udo, E.E.; Mathew, B.; Noronha, B.; Verghese, T.; Tappa, S.B. Livestock-Associated Methicillin-Resistant Staphylococcus aureus in Patients Admitted to Kuwait Hospitals in 2016-2017. Front. Microbiol. 2020, 10, 2912. [CrossRef] [PubMed]

37. Merz, A.; Stephan, R.; Johler, S. Genotyping and DNA microarray based characterization of Staphylococcus aureus isolates from rabbit carcasses. Meat Sci. 2016, 112, 86-89. [CrossRef] 
38. van der Mee-Marquet, N.L.; Corvaglia, A.; Haenni, M.; Bertrand, X.; Franck, J.-B.; Kluytmans, J.; Girard, M.; Quentin, R.; François, P. Emergence of a novel subpopulation of CC398 Staphylococcus aureus infecting animals is a serious hazard for humans. Front. Microbiol. 2014, 5, 652. [CrossRef]

39. Mitra, S.D.; Velu, D.; Bhuvana, M.; Krithiga, N.; Banerjee, A.; Shome, R.; Rahman, H.; Ghosh, S.K.; Shome, B.R. Staphylococcus aureus spa type t267, clonal ancestor of bovine subclinical mastitis in India. J. Appl. Microbiol. 2013, 114, 1604-1615. [CrossRef]

40. Antri, K.; Akkou, M.; Bouchiat, C.; Bes, M.; Martins-Simoes, P.; Dauwalder, O.; Tristan, A.; Meugnier, H.; Rasigade, J.-P.; Etienne, J.; et al. High levels of Staphylococcus aureus and MRSA carriage in healthy population of Algiers revealed by additional enrichment and multisite screening. Eur. J. Clin. Microbiol. Infect. Dis. 2018, 37, 1521-1529. [CrossRef]

41. Shore, A.C.; Lazaris, A.; Kinnevey, P.M.; Brennan, O.M.; Brennan, G.I.; Connell, B.; Feßler, A.T.; Schwarz, S.; Coleman, D.C. First Report of $c f r$-Carrying Plasmids in the Pandemic Sequence Type 22 Methicillin-Resistant Staphylococcus aureus Staphylococcal Cassette Chromosome mec Type IV Clone. Antimicrob. Agents Chemother. 2016, 60, 3007-3015. [CrossRef]

42. Guo, D.; Liu, Y.; Han, C.; Chen, Z.; Ye, X. Phenotypic and molecular characteristics of methicillin-resistant and methicillin-susceptible Staphylococcus aureus isolated from pigs: Implication for livestock-association markers and vaccine strategies. Infect. Drug Resist. 2018, 11, 1299-1307. [CrossRef]

43. Jaglic, Z.; Vlkova, H.; Bardon, J.; Michu, E.; Cervinkova, D.; Babak, V. Distribution, Characterization and Genetic Bases of Erythromycin Resistance in Staphylococci and Enterococci Originating from Livestock. Zoonoses Public Health 2012, 59, 202-211. [CrossRef] [PubMed]

44. Roberts, M.C. Update on macrolide-lincosamide-streptogramin, ketolide, and oxazolidinone resistance genes. FEMS Microbiol. Lett. 2008, 282, 147-159. [CrossRef] [PubMed]

45. El-Ashker, M.; Gwida, M.; Monecke, S.; El-Gohary, F.; Ehricht, R.; Elsayed, M.; Akinduti, P.; El-Fateh, M.; Maurischat, S. Antimicrobial resistance pattern and virulence profile of S. aureus isolated from household cattle and buffalo with mastitis in Egypt. Vet. Microbiol. 2020, 240, 108535. [CrossRef] [PubMed]

46. Khemiri, M.; Abbassi, M.S.; Couto, N.; Mansouri, R.; Hammami, S.; Pomba, C. Genetic characterisation of Staphylococcus aureus isolated from milk and nasal samples of healthy cows in Tunisia: First report of ST97-t267-agrI-SCCmec V MRSA of bovine origin in Tunisia. J. Glob. Antimicrob. Resist. 2018, 14, 161-165. [CrossRef]

47. Tan, L.; Li, S.R.; Jiang, B.; Hu, X.M.; Li, S. Therapeutic Targeting of the Staphylococcus aureus Accessory Gene Regulator (agr) System. Front. Microbiol. 2018, 9, 55. [CrossRef]

48. Chini, V.; Dimitracopoulos, G.; Spiliopoulou, I. Occurrence of the Enterotoxin Gene Cluster and the Toxic Shock Syndrome Toxin 1 Gene among Clinical Isolates of Methicillin-Resistant Staphylococcus aureus Is Related to Clonal Type Group. J. Clin. Microbiol. 2006, 44, 1881-1883. [CrossRef]

49. Alba, P.; Feltrin, F.; Cordaro, G.; Porrero, M.C.; Kraushaar, B.; Argudín, M.A.; Nykäsenoja, S.; Monaco, M.; Stegger, M.; Aarestrup, F.M.; et al. Livestock-Associated Methicillin Resistant and Methicillin Susceptible Staphylococcus aureus Sequence Type (CC)1 in European Farmed Animals: High Genetic Relatedness of Isolates from Italian Cattle Herds and Humans. PLoS ONE 2015, 10, e0137143. [CrossRef]

50. Becker, K.; Schaumburg, F.; Fegeler, C.; Friedrich, A.W.; Köck, R. Staphylococcus aureus from the German general population is highly diverse. Int. J. Med. Microbiol. 2017, 307, 21-27. [CrossRef]

51. Santos, V.; Gomes, A.; Ruiz-Ripa, L.; Mama, O.M.; Sabença, C.; Sousa, M.; Silva, V.; Sousa, T.; Vieira-Pinto, M.; Igrejas, G.; et al. Methicillin-Resistant Staphylococcus aureus CC398 in Purulent Lesions of Piglets and Fattening Pigs in Portugal. Microb. Drug Resist. 2020. [CrossRef]

52. Senok, A.C.; Somily, A.M.; Slickers, P.; Raji, M.A.; Garaween, G.; Shibl, A.; Monecke, S.; Ehricht, R. Investigating a rare methicillin-resistant Staphylococcus aureus strain: First description of genome sequencing and molecular characterization of CC15-MRSA. Infect. Drug Resist. 2017, 10, 307-315. [CrossRef]

53. Silva, V.; Almeida, F.; Carvalho, J.A.; Castro, A.P.; Ferreira, E.; Manageiro, V.; Tejedor-Junco, M.T.; Caniça, M.; Igrejas, G.; Poeta, P. Emergence of community-acquired methicillin-resistant Staphylococcus aureus EMRSA-15 clone as the predominant cause of diabetic foot ulcer infections in Portugal. Eur. J. Clin. Microbiol. Infect. Dis. 2019, 39, 179-186. [CrossRef] [PubMed]

54. Cuny, C.; Layer, F.; Hansen, S.; Werner, G.; Witte, W. Nasal Colonization of Humans with Occupational Exposure to Raw Meat and to Raw Meat Products with Methicillin-Susceptible and Methicillin-Resistant Staphylococcus aureus. Toxins (Basel) 2019, 11, 190. [CrossRef] [PubMed] 
55. Mama, O.M.; Morales, L.; Ruiz-Ripa, L.; Zarazaga, M.; Torres, C. High prevalence of multidrug resistant $S$. aureus-CC398 and frequent detection of enterotoxin genes among non-CC398 S. aureus from pig-derived food in Spain. Int. J. Food Microbiol. 2020, 320, 108510. [CrossRef] [PubMed]

56. Wulf, M.; Voss, A. MRSA in livestock animals-An epidemic waiting to happen? Clin. Microbiol. Infect. 2008, 14, 519-521. [CrossRef] [PubMed]

57. Petersen, A.; Stegger, M.; Heltberg, O.; Christensen, J.; Zeuthen, A.; Knudsen, L.K.; Urth, T.; Sorum, M.; Schouls, L.; Larsen, J.; et al. Epidemiology of methicillin-resistant Staphylococcus aureus carrying the novel mecC gene in Denmark corroborates a zoonotic reservoir with transmission to humans. Clin. Microbiol. Infect. 2013, 19, E16-E22. [CrossRef]

58. Kadlec, K.; Feßler, A.T.; Hauschild, T.; Schwarz, S. Novel and uncommon antimicrobial resistance genes in livestock-associated methicillin-resistant Staphylococcus aureus. Clin. Microbiol. Infect. 2012, 18, 745-755. [CrossRef]

59. Soares, G.M.S.; Figueiredo, L.C.; Faveri, M.; Cortelli, S.C.; Duarte, P.M.; Feres, M. Mechanisms of action of systemic antibiotics used in periodontal treatment and mechanisms of bacterial resistance to these drugs. J. Appl. Oral Sci. 2012, 20, 295-309. [CrossRef]

60. Argudín, M.A.; Cariou, N.; Salandre, O.; Le Guennec, J.; Nemeghaire, S.; Butaye, P. Genotyping and antimicrobial resistance of Staphylococcus aureus isolates from diseased turkeys. Avian Pathol. 2013, 42, 572-580. [CrossRef]

61. Sommer, M.O.A.; Church, G.M.; Dantas, G. The human microbiome harbors a diverse reservoir of antibiotic resistance genes. Virulence 2010, 1, 299-303. [CrossRef]

62. Petinaki, E.; Spiliopoulou, I. Methicillin-resistant Staphylococcus aureus among companion and food-chain animals: Impact of human contacts. Clin. Microbiol. Infect. 2012, 18, 626-634. [CrossRef]

(C) 2020 by the authors. Licensee MDPI, Basel, Switzerland. This article is an open access article distributed under the terms and conditions of the Creative Commons Attribution (CC BY) license (http://creativecommons.org/licenses/by/4.0/). 